\title{
Hatta, Politik Bebas Aktif dan Kapitalisme Dunia Masa Kini
}

\section{Malikul Kusno}

Peneliti muda dan mahasiswa Pasca Sarjana Universitas Padjadjaran Bandung.

\section{Albstract}

This article is aimed at rerflecting Hatta poliotical biography. His life span can be devided into three stages. First (19211932) when Hatta studied in Netherland; this period gave the greatest experience for Hatta due to his involvement in the worldwide interaction and organizations. Second (1932-1945) after he finished his education and came back to Indonesia; He put an emphasis on his political activities to unite the struggle vision and avoid internal fragmentation. Third (1945- 1956), this is the most complicated and critical period of Hatta political career. He for many times felt disappointed in politic

\section{Keywords}

Hatta; perjuangan politik, PN

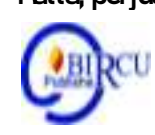

\section{Pendahuluan}

Biografi politik Mohammad Hatta memberikan pelajaran dan hikmah yang berharga bagi kita. Hatta lahir pada tanggal 12 Agustus 1902 di Bukittinggi, Sumatera Barat. Di kota kecil yang indah ini Bung Hatta - panggilan akrab Mohammad Hatta- dibesarkan dalam tradisi keluarga ibunya. Ayahnya, H. Muhammad Djamil, meninggal dunia ketika Hatta berusia delapan bulan. Dari perkawinan ayahnya itu, Hatta memiliki enam saudara perempuan. Ia adalah anak laki-laki satu-satunya. ${ }^{2}$

Hatta adalah anak kedua dari enam saudara, kakak perempuannya, Rafi'ah, dilahirkan dua tahun sebelumnya. Sejak bayi Hatta selalu dipanggil Attar oleh lingkungan keluarganya, yang berarti parfum dan juga nama seorang penyair terkenal Persia, dan seorang sufi yang disegani, yaitu Fariduddin Al Aththar. Percakapan Minangkabau mengubah nama Attar dengan nama Hatta. Kemudian nama Hatta dikenal sepanjang hidupnya.

Ayah Hatta, Haji Djamil merupakan salah satu ulama terkemuka di Minang-kabau. Ibu Hatta adalah isteri keempat Haji Djamil. Dalam tradisi Minangkabau, tidaklah aneh jika seseorang lelaki memiliki beberapa orang istri, terutama apabila ia selalu berpergian sebagai saudagar di antara pedalaman dan pantai. Dalam hal ini, Haji Muhammad Djamil memadukan dua unsur tradisi Minangkabau, perdagangan dan kewajiban beragama. Dalam masya-rakat adat Minangkabau, seorang ulama atau pemimpin diharapkan memi-liki kekayaan yang mencukupi sebagai bagian integral dari misi dakwah Islam.

Sejak kecil Hatta dikenal sebagai anak yang tekun dan disiplin dalam belajar. Ia adalah anak emas dari generasi yang tercerahkan. Kebijakan politik etis (ethics politics) yang diterapkan pemerintah kolonial Belanda memberikan akses kemudahan bagi sebagian kecil kaum pribumi, termasuk Hatta, untuk memperoleh pendidikan terbaik model Barat. Sikap pemerintah kolonial terhadap pendidikan kaum pribumi ini berlangsung sejak paruh kedua abad 19, yaitu sebagai konsekuensi dari kemenangan politik kaum Liberal, terutama fokus 
perhatiannya terhadap negeri jajahan. Untuk memajukan kepentingan ekonomi kaum Liberal di negeri jajahan, maka diperlukan perluasan birokrasi pemerintahan bagi kaum pribumi dalam sistem pemerintahan kolonial Belanda. Dengan demikian, pemerintah kolonial membutuhkan sumber daya manusia (SDM) yang berasal dari kalangan pribumi.

\section{Kajian Pustaka}

Latar belakang pendidikan Hatta sangat dipengaruhi oleh nilai-nilai keaga-maan dan kesukuan yang dianut dari keluarga ayah dan ibu serta masya-rakat Minangkabau pada umumnya. Dari garis keturunan ayah, Hatta mewariskan tradisi keislaman yang sangat kuat, dengan memperioritaskan pada kehidupan akhirat ketimbang kehidupan dunia yang bersifat sementara. Sedangkan dari pihak ibu, yang memiliki latar belakang sebagai pengusaha, Hatta mewariskan ilmu ekonomi (ilmu perdagangan) yang kemudian ditempuhnya sampai ke jenjang perguruan tinggi. Kedua hal itu sangat mempengaruhi pilihan-pilihan bagi studi Hatta.

Pendidikan Hatta pertama kali ditempuh di Europese Largere Scholl (ELS), setingkat sekolah dasar, di kota Bukittinggi, pada tahun 1916. Sejak duduk ELS, Hatta sering mengunjungi sebuah surau milik pamannya, Syekh Arsyad, di Batu Hampar, untuk mendalami ilmu agama. Syekh Arsyad meminta kepada ibu Hatta untuk mengizinkan anaknya mengikuti jejak sang Ayah mendalami ilmu keagamaan di Mekkah, Arab Saudi, yang kemudian dilanjutkan ke Universitas Al-Azhar di Kairo, Mesir.

Pandangan Syekh Arsyad bertolak belakang dengan keinginan sang ibu yang menginginkan supaya anaknya sekolah di tempat umum. Dalam pada itu, guru agama Hatta, Syekh Muhammad Jamil Jambek, juga mempunyai pandangan yang berbeda terhadap pendidikan Barat dibandingkan Syekh Arsyad. Syekh Jamil Jambek adalah salah satu tokoh pembaharu pemikiran Islam (modernisme Islam) di Minangkabau. Ia mendorong kaum modernis muslim untuk belajar dari Barat agar mampu menangkap semangat zaman dan melawan dominasi Barat, khususnya dalam penguasaan ilmu penge-tahuan dan teknologi (IPTEK). Visi keagamaan ini menyebar luas di kalangan kaum modernis muslim Minangkabau, dan merangsang mereka untuk mensekolahkan anaknya di sekolah umum. Dengan demikian, pihak ibu mendapatkan pembelaan yang sesuai dengan tuntutan dan aspirasinya.

Setelah menamatkan sekolah dasar dengan nilai yang cukup baik, Hatta berpeluang besar untuk bisa langsung melanjutkan sekolah ke Horger Burger Scholl (HBS), setingkat SMU, di Jakarta. Namun, usaha ini ditolak oleh ibunya, yang melihat Hatta masih sangat muda untuk tinggal sendiri di Jakarta dan terpisah dari keluarga. Namun demikian, ibunya meminta Hatta untuk terlebih dahulu belajar di Meer Uirgebreid Lagere School (MULO), setingkat SMP, di kota Padang. Mendengar keputusan itu Hatta kecewa; "karena saya bingung dan patah hati saya ingin berhenti sekolah dan mulai bekerja", kenang Hatta dalam memoarnya.4 Berkat dorongan dan semangat yang diberikan paman Saleh kepada Hatta, akhirnya Hatta berse-dia untuk melanjutkan sekolah di MULO.

Sejak duduk di MULO, Hatta tertarik dengan dunia pergerakan, yang waktu itu sedang marak bermunculan organisasi kepemudaan yang bersifat kedaerahan pada tahun 1916, seperti Jong Java, Jong Sumatranen Bond, Jong Minahasa, Jong Ambonese.5 Hatta masuk dalam organisasi Jong Sumatranen Bond (organisasi kepemudaaan Sumatera) sebagai bendahara. Setelah tamat dari MULO, ia melanjutkan sekolahnya ke Handel Middlebare Scholl (HMS), atau sekolah dagang, di Jakarta. Di kota inilah, Hatta banyak berkenalan dengan tokoh-tokoh pergerakan nasional, seperti Abdul Muis dan Haji Agus Salim, dll, yang telah dikenalnya ketika berada di Jong Sumatrenan Bond (JSB). 
Pertemuan dengan beberapa tokoh pergerakan nasional di Jakarta, meng-inspirasikan secara radikal gerak maju pemikiran Hatta, khususnya tentang kemerdekaan Indonesia. Secara khusus perkembangan pemikiran politik Hatta dapat dibagi ke dalam empat periode:

\section{Pembahasan}

\subsection{Periode Pertama (1921 - 1932)}

Periode 1921-1932, merupakan masa perkuliahan Hatta di Belanda. Di negeri kolonial itu gravik pemikiran Hatta mengalami perkembangan yang signifikan, seiring dengan meluasnya pergaulan dan pengalaman di orga-nisasi serta kegiatan politik yang langsung bersentuhan dengan pemerintah pusat Belanda. Terhadap perjuangannya itu Hatta berkomentar; "perjuang-an kemerdekaan Indonesia pada saat yang sama merupakan perjuangan bagi demokrasi dan bagi kemanusiaan universal", sedangkan pencapaian demokrasi dan kemanusiaan sebagai tujuan utama dalam perjuangan kemerdekaan, hanyalah sekedar pemindahan kekuasaan dari pemerintah kolonial Belanda kepada rakyat Indonesia.

Di Belanda, Hatta melanjutkan studinya pada Rotterdam Handelsho-geshool, Amsterdam. Bagi pamannya, Syekh Arsyad, keputusan Hatta untuk meneruskan studi ke negeri Barat, telah menciptakan kontroversi dan kekecewaan dari pihak keluarga Ayah, "aku dapat merasakan bahwa pamanku, Syekh Arsyad, sangat kecewa bahwa aku akan pergi ke Belan-da", tulis Hatta.8 Syekh Arsyad merasakan bahwa kepergian Hatta ke Belanda merupakan hilangnya seorang yang genuine yang mampu meracik gagasan ideal dengan konsistensi pengabdian secara terus-menerus. Dua unsur doktriner yang menurut Syekh Arsyad sangat mendukung prinsip-prinsip sebuah surau. Pertemuan itu pun menjadi petanda akhir dari perjumpaan dirinya dengan Hatta. Ia meninggal dunia sebelum Hatta pulang dari Belanda.

Kepergian Hatta ke Belanda diawali dengan singgah terlebih dahulu ke kampung halamannya di Minangkabau, untuk memohon doa restu dari kerabat keluarga serta rekanrekannya di Jong Sumatranen Bond (JSB). Pada tanggal 3 Agustus 1921, Hatta berlayar dari Teluk Bayur -yang pada waktu itu dikenal sebagai Emnaheaven, atau pelabuhan Padangbersama dengan tiga orang pelajar Indonesia yang akan menuju Universitas Leiden. Perjalanan laut ditempuh selama satu bulan, dengan singgah di kota Marseilles, Perancis.

Dalam memoarnya, ia melukiskan tentang perasaan pribadinya ketika kapal berlabuh di Marseilles, Perancis, Hatta yang mahir berbahasa Perancis mampu berkomunikasi secara aktif dan fasih, sehingga sangat membantu di antara sesama penumpang.

Tahun pertama di Belanda, Hatta mendapati sikap berbeda yang diperli-hatkan oleh masyarakat Belanda. Dalam hal ini, Hatta merasakan adanya perbedaan yang sangat menyenangkan antara kehidupan di tanah jajahan dengan tempat tinggalnya di Eropa, yaitu menurunnya diskriminasi rasial. Namun demikian, perasaan itu telah mengundang dilema psikologis dalam perjuangannya untuk mengusir pemerintah kolonial Belanda. Ia dipaksa untuk berempati kepada orang-orang Eropa, sehingga menghilangkan rasa permusuhan dan sintemen anti kolonialisme.

Sikap anti penjajahan tidak sepenuhnya hilang dari ingatan Hatta. Hari kedua tinggal di Belanda, pemerintah kolonial kembali mempraktekkan sikap diskriminatif dengan melokalisir tempat tinggal para mahasiswa Indonesia. Selanjutnya pemerintah Belanda meminta Westenenck, mantan asisten residen di Bukittinggi, untuk menjadi penasihat bagi para maha-siswa Indonesia. Bagi Hatta tugas itu merupakan bentuk kontrol pemerintah terhadap aktifitas mahasiswa, khususnya kaum intelektual yang memiliki afiliasi dengan gerakan Sosialisme dan Komunisme internasional. 
Pada tahun 1921, terjadi penerimaan secara besar-besaran terhadap pemi-kiran Karl Marx (1818-1883), khususnya di Eropa. Kebanyakan mahasiswa Indonesia yang belajar di Eropa, memahami betul gagasan Marx sebagai pisau analisa bagi perubahan sosial-politik di tanah air. Salah satu doktrin Marx yang terkenal dan mempengaruhi Hatta adalah gagasannya tentang emansipasi manusia.11 Dalam perspektif Marx suatu masyarakat yang adil dan manusiawi akan berkembang melalui upaya massa rakyat yang tertindas secara ekonomi. Dalam kaitan itu, Hatta menuliskan bahwa kekayaan yang diperoleh melalui tenaga orang lain merupakan penyebab terbesar dari dekadensi dan demoralisasi yang terjadi di ranah Indonesia.

Untuk mendukung aktifitas pergerakannya itu, Hatta bergabung dalam Perhimpunan Indonesia (Indische Vereniging) yang merupakan kepan-jangan tangan dari pelbagai organisasi kepemudaan daerah. Sekitar bulan Februari 1922, Hatta ditunjuk untuk menduduki jabatan sebagai Benda-hara.13 Sebagai pengurus harian, ia diminta untuk menjadi dewan redaksi jurnal Hindia Poetra yang dibiayai oleh Liga Mahasiswa Indonesia, suatu federasi mahasiswa Belanda, Cina dan Indonesia yang tertarik dengan Hindia-Belanda. Namun, radikalisme pemikiran yang muncul belakangan di kelompok mahasiswa telah menempatkan kemerdekaan sebagai tema sen-tral dari penulisan jurnal. Sehingga nama jurnal Hindia Poetra diganti menjadi Indonesia Merdeka, sesuai dengan keinginan mahasiswa atas asas nonkooperasi dan tuntutan kemerdekaan sepenuhnya bagi Indonesia.

Sepanjang tahun 1922 sampai dengan tahun 1923, Hatta dikenal sebagai propagandis terkemuka Perhimpunan Indonesia (PI). Ia mulai dikenal lewat tulisan-tulisannya yang kritis dan tajam. Dengan menggunakan keahlian ekonomi yang baru saja diperolehnya, ia menggugat kelemahan teori Barat yang dikemukakan oleh ahli ekonomi Belanda, Dr. Boeke. Dalam tesisnya Boeke mengemukakan bahwa ada perbedaan mendasar dalam pandangan Timur dan Barat. Secara general, petani Timur hanya memiliki keinginan yang sederhana dan terbatas, berbeda dengan petani Barat yang memiliki naluri keinginan yang tidak terbatas. Di samping itu, para petani Timur tidak memiliki kemampuan organisasi yang baik untuk membentuk peru-sahaan dalam skala besar, dan kurang memiliki sifat mencari keuntungan seperti yang dimiliki oleh orang Barat. Tesis ini dengan tegas ditolak Hatta, ia menyatakan bahwa hukum ekonomi yang berlaku di Barat tidak berlaku bagi rakyat pribumi di HindiaBelanda.

Tak puas dengan jurnal Indonesia Merdeka, pada tahun 1925 Perhimpunan Indonesia (PI) menerbitkan Gedenboek, buku peringatan pertama lima belas tahun berdirinya organisasi mahasiswa itu. Para penulis dalam buku itu menekankan prinsip-prinsip non-kooperasi dan mengajukan penggantian nama kesatuan politik Hindia Timur Belanda dengan Indonesia. Dua tulisan Hatta, yaitu Indonesia di Tengah Revolusi Asia dan Indonesia di Masya-rakat Dunia dengan tegas menjelaskan kebangkitan Asia yang terjadi secara endemik dengan didorong oleh keberhasilan Jepang dan Turki, serta mun-culnya kekuatan kaum nasionalis di India yang dipelopori oleh Mahatma Gandhi.

Merebaknya aksi protes dan perlawanan kaum mahasiswa Indonesia, memi-cu sikap reaksioner pemerintah Belanda. Westenenck ditugasi untuk me-ningkatkan pengawasan dan kewaspadaan terhadap pergerakan maha-siswa, karena tak pelak lagi, mereka telah membangun jaringan kerja (networking) dengan kelompok-kelompok sayap kiri internasional. Terhadap aktifitas yang semakin luas itu, Hatta kemudian dicalonkan menjadi ketua umum Perhimpunan Indonesia. Dengan sikap terbuka Hatta bersedia menerima kedudukan itu.

Dalam pidato pelantikan sebagai ketua umum Perhimpunan Indonesia, Hatta menyoroti akar-akar persoalan ekonomi kolonial yang diberi judul Struktur Dunia Ekonomi dan Konflik Kekuasaan. Dalam hal ini, Hatta merujuk pada filsafat Hegel yang diangkat oleh Marx, 
bahwa keberadaan konflik merupakan syarat utama bagi perkembangan masyarakat.14 Dari materialisme dialektika Marx, Hatta menguraikan hal ihwal konflik yang terjadi dalam masyarakat Indonesia, yaitu karena adanya situasi rasial yang diciptakan kolonial yang merupakan antitesis dari penguasa dan yang dikuasai, atau antara ras kulit putih dengan kulit berwarna. Hatta secara agresif menyatakan, "tidak akan ada kemerdekaan tanpa kekerasan, karena kepentingan penguasa jajahan ialah bertahan dengan segala ma-cam cara". Inti pidato itu ingin mengecam sistem ekonomi dan kelem-bagaan pemerintah kolonial, tetapi menolak saran pemberontakan bersen-jata (revolusi fisik). Menurut Hatta, orang Indonesia memiliki kekuatan ekonomi dan kemampuan untuk mengorganisir, hanya jika mereka menge-tahui bagaimana cara memanfaatkannya.

Sementara itu, di Eropa telah dibentuk liga internasional yang bertujuan melawan kekuatan Imperialisme dan Kolonialisme serta memperjuangkan kemerdekaan bagi setiap negara jajahan. Bagi kaum nasionalis Indonesia yang tinggal di Eropa, hal ini merupakan kesempatan emas untuk mem-peroleh legitimasi internasional yang lebih luas bagi Indonesia. Liga itu pertama kali diadakan oleh Partai Komunis Jerman di bawah pimpinan Willi Munzenberg, dan akan menyelenggarakan kongresnya di Brussel pada tanggal 10-15 Februari 1927. Hatta menghadiri kongres itu sebagai delegasi kehormatan dari perhimpunan Indonesia.

Dalam gelanggang politik internasional, nama Hatta semakin luas dikenal publik internasional. Untuk pertama kali, sebagai presidium, Hatta bekerja-sama dengan Jawaharlal Nehru dari India. Pertemuan itu kemudian menjadi titik balik paling penting dalam hubungan persahabatan antara Hatta dengan Nehru. Seperti halnya Hatta, Nehru menolak praktekpraktek komunisme atau marxisme-leninisme yang terjadi di Uni Soviet. Mereka menolak kediktatoran partai komunis Uni Soviet yang menggunakan cara-cara kekerasan untuk melegitimasikan kekuasaan. Namun, kedua tokoh itu mendukung politik non-kooperasi dan non-kekerasan. Hatta dan Nehru sepakat untuk menghargai penjajah sebagai manusia, namun keduanya melihat bahwa praktek kolonialisme berakibat fatal merusak pada penjajah apabila ia menggunakan kekuasaan despotik di koloninya, ketimbang mem-biarkan derajat demokrasi yang diterapkan di negeri induknya.

Sementara itu, dari Hindia dilaporkan bahwa seorang nasionalis veteran, Dr. Tjipto Mangunkusumo dikabarkan telah ditangkap dan diasingkan ke Banda Neira, Kepulauan Maluku, oleh pemerintah Belanda atas tindakannya sebagai mesin penggerak Kelompok Studi Bandung yang dipelopori oleh Soekarno. Hatta membela Tjipto, dengan menuliskan sebuah artikel yang bernada keras di Recht en Vriheid, sebuah jurnal Liga Melawan Kolonialis-me, dan sekaligus menorehkan apresiasinya terhadap tokoh pergerakan nasional itu.

Tulisan Hatta dimuat pada tanggal 24 September 1927, tetapi sehari sebelum itu, setelah kunjungannya ke Switzerland, Hatta mendapati dua orang polisi Belanda mendatangi kediamannya dengan membawa surat perintah pena-hanan. Hatta ditahan bersama tiga orang rekannya dari PI, yaitu Nazir Pamuntjak, Ali Sastroamidjojo dan Abdul Madjid. Sedangkan Subardjo, Gatot Tarumihardjo, dan Arnod Mononutu lolos dari penangkapan karena sedang berada di luar Belanda. Hatta bersama ketiga rekannya dituduh telah merencanakan tindakan subversif atau penggulingan kekuasaan dengan menggunakan cara-cara kekerasan terhadap pemerintah Hindia-Belanda.

Pada tanggal 8 Maret 1928 Hatta diadili oleh Mahkamah, di Den Haag. Dalam prosesi persidangan yang dilakukan selama berbulan-bulan itu, Hatta didampingi oleh dua orang pengacara yang juga anggota parlemen dari Fraksi Partai Buruh Sosialis, Dr. J.E.W Duys dan Mr. Mobach. 
Dalam pidato pembelannya yang berjudul Indonesia Merdeka, Hatta meyangkal semua tuduhan yang ditujukan kepada dirinya. Setelah melalu perdebatan di pengadilan, akhirnya Hatta dibebaskan dari segala tuduhan pada tanggal 22 Maret 1928.

Setelah pembebasan empat orang mahasiswa, pemerintah kolonial Belanda semakin bertindak represif terhadap pergerakan mahasiswa. Pembela hu-kum mereka, Duys, mengingatkan kepada empat orang mahasiswa itu, bahwa nasib serupa akan terulang jika mereka terus menerus berpartisipasi dalam aktifitas pergerakan sesampainya di HindiaBelanda. Mereka akan ditangkap dan diasingkan ke tempat pengasingan paling ganas di Boven Digul, Irian Barat.

Menjelang akhir tahun 1929, Hatta menyatakan komitmennya kepada PI bahwa ia tidak bersedia lagi dicalonkan sebagai ketua umum PI. Kemudian sebagai penggantinya ia menunjuk seorang mahasiswa Fakultas Hukum yang berasal dari Ambon. Aktifitas Hatta kemudian lebih banyak difokuskan bersama Sutan Sjahrir dengan melibatkan diri pada pedagogi sosial. Mereka mengkritik patologi sosial yang menghimpit sistem kepemimpinan aris-tokrasi Jawa yang menghilangkan asas egaliter. Gagasan itu diterima oleh beberapa kelompok dalam PNI yang kecewa terhadap tindakan sepihak Sartono untuk membubarkan PNI setelah penangkapan Soekarno. Mereka kemudian membentuk Golongan Merdeka yang didukung oleh Hatta dan Sjahrir.

Pada tanggal 9 November 1931 pengurus PI memutuskan bahwa Hatta dan Sjahrir dikeluarkan dari Perhimpunan Indonesia atas tuduhan telah meme-cah-belah gerakan nasionalis dengan mendukung Golongan Merdeka. Da-lam pandangan Hatta, keputusan itu mengesankan adanya infiltrasi politik yang dilakukan kaum komunis dengan jalan menempatkan PI di bawah subordinasi kaum komunis. Hatta menyesalkan persekutuan yang dilakukan pengurus PI dengan Moskow.

Kecewa dengan keputusan itu, Hatta melanjutkan kegiatan politiknya de-ngan bergabung bersama Pendidikan Nasional Indonesia (PNI) yang didiri-kan pada tanggal 27 Desember 1931 di Yogyakarta. Dalam hal ini, Hatta mengharapkan supaya Pendidikan Nasional Indonesia menjadi kelompok filsafat politik yang terorganisir.17 Untuk membedakan kelompok tersebut dengan PNI Soekarno yang dilarang oleh pemerintah kolonial, Pendidikan Nasional Indonesia mengubah namanya dengan Pendidikan Nasional Indo-nesia (PNI) Baru.

Pada bulan Juli 1932, Hatta mengikuti ujian akhir yang menentukan bagi kelulusan studinya. Ia kemudian dinyatakan lulus sebagai sarjana ekonomi dengan gelar doctorandus setelah menempuh perkuliahan selama sebelas tahun. Tanggal 20 Juli 1932, Hatta kembali ke Indonesia dengan menggu-nakan kereta api dari Rotterdam menuju Paris kemudian ke Genoa, di mana ia kemudian naik kapal Jerman, Saarbrucken, menuju Singapura. Setibanya di pelabuhan Tanjung Priok, ia disambut dengan hangat oleh para keluaraga dan teman-teman serta sebagian besar anggota PNI Baru dengan antusiasme yang tinggi.

\subsection{Periode Kedua ( 1932- 1945)}

Setelah meyelesaikan gelar kesarjanaan ekonomi di Belanda, Hatta kembali meningkatkan aktifitas politiknya di tanah air bersama oraganisasi PNI Baru. Situasi politik di dalam negeri menjelang tahun 1930-an sedang memanas, menyusul insiden penangkapan tokoh nasionalis ternama, Soekarno. Pemerintah kolonial Belanda kemudian melakukan penyensoran dan penga-wasan secara ketat terhadap seluruh aktifitas pergerakan nasional. Seperti dikatakan Duys sebelumnya, bahwa pemerintah kolonial tidak akan segan-segan untuk menindak kaum intelektual yang melakukan perlawanan dan mengasingkannya ke tempat pembuangan paling kejam di Boven Digul, Irian Barat. 
Untuk sementara waktu, Hatta memperioritaskan kegiatan politiknya de-ngan melakukan konsolidasi politik untuk menyatukan visi perjuangan serta menghindari fragmentasi internal yang lebih luas akibat tuduhan-tuduhan yang dilancarkan kelompokkelompok tertentu kepada dirinya. Setelah dua minggu berada di Jakarta, Hatta berkesempatan melakukan pertemuan per-tama dengan Soekarno. Ia didampingi Haji Usman yang bersedia meng-antarkannya ke Bandung. Sebelum itu, Haji Usman menyarankan kepada Hatta, " meskipun anda tergolong dalam partai yang berbeda, sangat baik jika anda mengenalnya". Dalam bayangan Hatta pertemuan pertama de-ngan Soekarno akan terasa tegang, mengingat kekecewaan yang muncul di antara keduanya, bahkan sebelum peristiwa tatap muka terjadi.

Tepat pukul sembilan malam, Soekarno menemui Hatta di sebuah hotel di Bandung. Dalam pertemuan itu tidak sedikitpun persoalan politik yang dibahas. Hatta merasakan pertemuan itu sama sekali tidak berguna. Mung-kin karena hadirnya Haji Usman, sehingga Soekarno tidak bersedia untuk memperbincangkan secara luas persoalan Partai Indonesia yang dipimpin-nya dengan PNI Baru.

Pada bulan Oktober 1932, Hatta menyempatkan waktu untuk kembali ke Minangkabau, di tengah kegalauan politik yang semakin tidak menentu. Hatta merasakan suatu kebahagiaan dapat bertemu kerabat keluarga dan teman-teman seperjuangannya di Minangkabau. Kunjungan Hatta menda-pat pengawasan cukup ketat dari kepolisian Belanda yang mencurigai Hatta telah membangun kekuatan politik untuk melumpuhkan penjajah. Akibatnya, suatu tindakan konspiratif dilakukan untuk mencegah keberadaan dirinya. Ketika berkendaraan ke luar kota Padang, di mana mobil yang di-tumpangi Hatta dipaksa ke luar jalan raya oleh sebuah kendaraan tak dikenal. Hatta mengalami kecelakaan, dengan luka kecil dan keseleo di tangan. Setelah kejadian itu, Hatta dipanggil oleh asisten residen untuk segera meninggalkan wilayah Sumatera, karena ia telah dinyatakan sebagai orang terlarang di kawasan tersebut.

Perintah larangan itu mengingatkan Hatta supaya bertindak lebih hati-hati. Di samping itu, kelompok PNI Baru mengalami tekanan yang sama dari pemerintah. Pada bulan Januari 1933, pengurus PNI Baru cabang Surabaya ditangkap setelah mengeluarkan pernyataan politik yang berisikan: "Rakyat Indonesia harus memiliki semangat revolusioner - dari perbudakan me-nuju kemerdekaan ". Namun demikian, keberadaan organisasi tetap eksis dan berkembang. Enam bulan setelah Hatta kembali dari Belanda, kedua belas cabangnya telah berkembang menjadi 66. Sebagaimana dikemukakan I Wangsa Widjaja, seorang anggota PNI Baru yang kemudian menjadi sekre-taris pribadi Bung Hatta: "Hatta dan Sjahrir adalah pemimpin yang dina-mis, kedatangannya membuat pengkaderan organisasi menjadi meningkat".

Sekitar bulan Juli hingga Agustus 1933, Hatta mengkonsentrasikan aktifitas-nya di Jawa Tengah yang waktu itu menjadi pusat radikalisme, di mana PKI telah membangun kekuatan signifikan di bawah kepemimpinan Semaun dan Darsono. Hatta mengamati intervensi kepolisian yang semakin ketat, sehing-ga menyulitkannya untuk pidato di forum terbuka. Akhirnya, aktifitas per-gerakan dialihkan ke tempat-tempat kediaman pribadi. Di Semarang, Hatta mengadakan kontak dengan serikat pekerja kereta api, yang waktu itu mendapat tekanan dari pemerintah kolonial. Pada tanggal 27 Juli dikeluarkan undang-undang pelarangan kepada pegawai negeri untuk berafiliasi dengan kedua partai terkemuka, PNI Baru dan Pertindo. Pelanggaran terhadap peraturan tersebut berakibat pemecatan.

Semasa Hatta di Semarang tersiar kabar bahwa Soekarno telah ditangkap lagi. Berkaitan dengan itu, Hatta berusaha menenangkan kepanikan yang melanda kaum nasionalis. Ia mengingatkan kepada rakyat Indonesia bahwa mereka bukanlah satu-satunya rakyat yang menderita akibat kekejaman rezim penindas. Hatta memberikan contoh 
Mustapha Kemal Pasha, yang meskipun dicap sebagai pemberontak oleh pemerintah, tetapi kemudian disanjung sebagai seorang pahlawan nasional.

Dengan diasingkannya Soekarno ke pulau Flores, maka tonggak pergerakan nasional diserahkan kepada Hatta. Sehubungan dengan pelarangan PNI Baru oleh pemerintah, Hatta menolak saran rekan-rekannya supaya PNI Baru dibubarkan saja dan pergerakan dilakukan secara informal, supaya membingungkan pemerintah. Tak pelak lagi, konsep itu mengingatkan pembubaran PNI lama yang pernah dikritiknya dengan keras. Hatta mulai memperkuat hubungannya dengan kelompok PNI lama, dengan menyeleng-garakan diskusi pada bulan Desember bersama Sartono, untuk menjamin kerjasama yang lebih erat antara Partindo dengan PNI Baru.

Namun, kegiatan itu mendapatkan sorotan tajam dari pemerintah Belanda. Jaksa Agung menyarankan kepada De Jonge untuk melakukan pembersihan terhadap gerakan nasionalis. Dalam laporannya kepada Gubernur Jenderal pada bulan Januari 1934, supaya PNI Baru dibubarkan dan pemimpinnya ditangkap apabila mereka tetap bersikukuh melakukan kegiatan politik. Pada tanggal 25 Februari 1934, hanya beberapa minggu setelah Soekarno dibuang ke Flores, untuk kedua kalinya Hatta dijemput pihak kepolisian.

Hanya enam bulan berada di penjara Glodok, Hatta bersama Sjahrir di asingkan ke Boven Digul, Irian Barat pada tanggal 16 November 1934. Hatta dinyatakan bersalah setelah selama berada di Belanda sampai dengan tahun 1931 berafiliasi dengan kelompok ekstrimis sayap kiri internasional yang berpusat di Berlin dan memimpin pergerakan revolusioner untuk menja-tuhkan pemerintahan yang legitim.

Pada bulan Januari 1935 Hatta dikirim ke Boven Digul dengan menggu-nakan kapal KPM Melchior Treub. Barangkali karena klasifikasi mereka sebagai kaum terpelajar, Hatta dan Sjahrir ditempati di kabin kelas dua, sedangkan sisa anggota kelompok lainnya ditempatkan di dek penumpang. Setibanya di Boven Digul, Hatta tidak menyiakan waktu dengan sia-sia. Ia lebih suka memanfaatkan cuaca dingin pagi hari untuk belajar dan menulis. Sebelumnya, ia ditawari kontrak untuk menulis di harian umum Peman-dangan.

Pada bulan Maret 1935, Hatta menulis surat kepada kakak iparnya, suami Rafiah, bahwa ia berkeinginan untuk membangun sebuah rumah yang lebih baik, yang bisa bertahan sekitar sepuluh tahun. Pemerintah kolonial menye-diakan seng, dan kaum buangan diminta memotong kayu pepohonan di hutan sekitarnya. Tanpa disadari surat itu dikirimkan ke surat kabar Indo-nesia dan Belanda, sehingga menimbulkan reaksi keras, baik di Hindia maupun di Belanda sendiri. Dalam keterangannya di Tweede Kamer, Perda-na Menteri Colijn menekankan bahwa pembuangan Hatta ke Boven Digul tidak diperuntukkan untuk menghancurkan eksistensinya, melainkan bertu-juan mengasingkan dirinya dari masyarakat luas.

Untuk membendung aksi protes yang merebak, pemerintah Belanda pada bulan November 1935 memerintahkan supaya Hatta dan Sjahrir dipindah-kan ke Banda Neira, Maluku. Hatta menyambut keputusan itu dengan suasana haru dan senang. Sebagai konsesi pemindahan itu, pemerintah kolonial meminta Hatta dan Sjahrir untuk bersedia menandatangani surat pernyataan bahwa mereka berdua tidak akan bergabung kembali dalam kancah politik. Hatta dan Sjahrir menyetujui hal tersebut dengan bersedia untuk mundur dari kegiatan politik. Suatu keputusan yang berat diterima oleh Hatta.

Sementara itu, dalam ranah politik internasional, bangsa-bangsa Eropa dilanda krisis politik yang tajam, yang menyeretnya ke dalam Peperangan pada bulan September 1939. Hal ini memungkinkan tumbuhnya rasa persa-tuan di kalangan kaum nasionalis Indonesia, mereka merasakan semakin dekat pergolakan internasional yang terjadi dalam volume yang besar. Pada bulan Mei 1939, dibentuk Front Nasionalis Baru, yaitu Gabungan Politik Indonesia (GAPI) yang menganut slogan "Indonesia Berparlemen" sebagai-mana 
dibayangkan dalam janji November 1918. Pada bulan Desember 1939 GAPI menyelenggarakan kongres rakyat Indonesia. Dalam pada itu, dilaku-kan perubahan kecil atas bendera yaitu dengan menghilangkan gambar kepala banteng dan menyisakan dua garis horisontal, berwarna merah dan putih, yang kemudian menjadi bendera resmi bangsa Indonesia.

Pada tahun 1941 kekuatan Fasisme Jepang semakin menguat, sehingga me-munculkan kekhawatiran pemerintah kolonial Belanda tentang penak-lukan Jepang terhadap HindiaBelanda. Kehawatiran itu semakin menjadi, ketika pada bulan Desember 1941, Jepang berhasil menghancurkan benteng perta-hanan Amerika Serikat, Pearl Harbor, yang menandai dimulainya Perang Pasifik.20 Gubernur Jenderal mengeluarkan pernyataan resmi bahwa Hindia berada dalam situasi perang. Banda Neira dimobilisasi ke dalam pertahanan sipil, dan secara spontan Hatta dan Sjahrir turut serta di dalamnya.

Pada tanggal 1 Januari 1942, sebelum Jepang berhasil mengambilalih keku-asaan Hindia, Hatta dan Sjahrir dipindahkan ke pulau Jawa atas desakan pemerintah kolonial Belanda. Setibanya di Surabaya, Hatta dan Sjahrir langsung diboyong ke Sukabumi, Jawa Barat untuk ditempatkan di Sekolah Kepolisian. Mereka diperbolehkan secara bebas untuk bergerak di wilayah Sukabumi, tetapi dilarang berpergian jauh dari tempat itu.

Dominasi militer Jepang pada episode awal perang Pasifik menyulitkan pasukan Sekutu, sehingga mereka harus mengakui kekalahan terlebih dahu -lu dalam perang Dunia II. Seiring dengan itu, pada tanggal 9 Maret 1942 pemerintah Belanda menyerah kepada tentara Jepang, setelah dua minggu pendaratannya di pulau Jawa. Keruntuhan Belanda begitu cepat, dan tanpa disadari oleh rakyat Indonesia bahwa kekuasaan mereka kini telah berakhir, tanpa suatu perlawanan hebat seperti yang diprediksikan bayak pihak. Situasi ini menandai berakhirnya fase pengasingan bagi Soekarno Hatta dan Sjahrir.

Kemenangan Jepang terhadap pemerintah Hindia-Belanda tidak banyak mengubah sikap dan pandangan Hatta terhadap kemerdekaan Indonesia. Menurut Hatta, tidak ada yang patut digembirakan dari kemenangan Jepang itu, bangsa Indonesia harus lebih realistis menerima kenyataan bahwa Indonesia akan mengalami kembali kekuasaan asing di bawah payung kuasa Jepang. Namun demikian, sikap Jepang yang berusaha untuk mengakomodasi kemerdekaan bagi Indonesia, mendapatkan perhatian serius dari Soekarno dan Hatta untuk bekerjasama mewujudkan kemerdekaan Indo-nesia dengan pemerintah Jepang. Sepanjang tahun 1942 sampai dengan tahun 1945, Jepang berhasil mem-bangun hubungan baik dengan para elit politik Indonesia, khususnya Soekarno dan Hatta. Namun, badai dan krisis yang terjadi sepanjang tahun 1945, dengan kembalinya kekuatan Sekutu di kawasan Pasifik, telah mele-mahkan posisi Jepang. Soekarno dan Hatta telah dicap sebagai kelompok Fasis dan penjahat perang oleh pihak Sekutu, akibat sikap kooperatif yang diperlihatkannya kepada Jepang. Berkaitan dengan itu, Soekarno dan Hatta meminta Jepang untuk meningkatkan latihan militer bersama yang telah disetujui dengan pembentukan tentara gabungan Pembela Tanah Air (PETA), untuk membendung kembalinya kekuasaan Belanda di Indonesia, tetapi harapan itu sia-sia.

Pada tanggal 14 Agustus 1945, pesawat-pesawat tempur Amerika Serikat menjatuhkan bom atom di Hiroshima dan Nagasaki, yang menyebabkan 2 juta orang sipil terbunuh. Dua hari kemudian, setelah peristiwa Hiroshima dan Nagasaki, Jepang takluk kepada tentara Sekutu. Sementara itu di dalam negeri, berita kekalahan Jepang diketahui oleh sekolompok pemuda yang dikomandani oleh Sjahrir. Dalam pandangan kaum muda penaklukan Je-pang oleh Sekutu merupakan momentum besar bagi rakyat Indonesia untuk memproklamirkan kemerdekaan.

Usul itu ditolak Soekarno dan Hatta yang telah terlanjur berkompromi de-ngan Jepang. Dalam pandangan Hatta, kemerdekaan Indonesia hanya bisa dilakukan dengan mekanisme 
yang telah disetujui melalui Panitia Persiapan Kemerdekaan Indonesia (PPKI). Sikap Soekarno dan Hatta menyulutkan kemarahan di kalangan pemuda. Mereka berencana menculik Soekarno dan Hatta serta memaksanya untuk menyatakan kemerdekaan bagi Indonesia. Dalam peristiwa Rengas Dengklok yang penuh dengan perdebatan, Soekarno dan Hatta akhirnya bersedia menandatangi naskah proklamasi yang akan dibacakan pada hari Jum'at tanggal 17 Agustus 1945. Selanjutnya Soekarno dan Hatta secara bulat terpilih menjadi presiden dan wakil presiden dengan usul tegas bahwa jabatan itu diperuntukkan secara khusus bagi Dwi-tunggal.

\subsection{Periode Ketiga (1945- 1956)}

Periode 1945-1956, merupakan masa sulit dan kritis dalam sejarah karir politik Hatta. Pasca proklamasi kemerdekaan, Indonesia segera memasuki masa suram dalam periode perang dan revolusi. Sebagaimana dikatakan oleh sejarawan Taufik Abdullah, dalam periode perjuangan fisik, ada peris-tiwa yang dipenuhi oleh janji-janji, tetapi banyak pula yang menggoreskan kekecewaan mendalam dalam kesadaran kolektif bangsa. Dari penaklukan kembali kolonialisme Belanda atas beberapa wilayah Indonesia, revolusi ke revolusi, sampai kepada coup d' etat terhadap pemerintahan yang sah pada masa awal kemerdekaan.

Dalam kedudukannya sebagai Wakil Presiden Hatta memiliki fungsi sentral, bersama dengan Presiden, untuk membuat rumusan dasar tentang konsep kenegaraan Indonesia. Dalam hal ini, beberapa keputusan penting dikeluar-kan dalam rangka memperkuat posisi pemerintah di hadapan publik inter-nasional.23 Harus diakui bahwa dalam sejarah baru yang kritis itu, euforia kemerdekaan telah menjadi impetus bagi seluruh tradisi politik untuk berjuang mengaktualisasikan agenda politik mereka.

Situasi yang terakhir ini menyulutkan terjadinya pertarungan kekuasaan secara internal dan pertarungan ideologis yang tercermin dengan begitu singkatnya usia kabinet-kabinet pada masa awal kemerdekaan. Sejak 19 Agustus 1945 sampai dengan 20 Desember 1949, negara Indonesia meng-alami jatuh bangun sembilan kabinet yang masing-masing usianya tidak lebih dari dua tahun.24 Namun demikian, meski terjadi fragmentasi, kelom-pok-kelompok blok historis masih bertahan selama beberapa waktu karena adanya kehendak bersama untuk melawan agresi dari luar.

Melalui peperangan dan negosisasi yang alot, selama masa revolusi kemer-dekaan, Indonesia akhirnya mencapai kedaulatannya secara formal dan legal. Konferensi Meja Bundar (KMB) di Den Haag, yang diselenggarakan sejak tanggal 23 Agustus sampai 2 November 1949, mengakui tanpa syarat dan sepenuhnya, sebelum tanggal 30 Desember 1949, kedaulatan Belanda atas semua wilayah jajahan Hindia-Belanda, terkecuali Irian Barat, kepada negara Republik Indonesia Serikat (RIS).

Selanjutnya Soekarno diangkat sebagai Presiden RIS dan Mohammad Hatta sebagai Wakil Presiden merangkap Perdana Menteri (1949-1950) RIS. Re-publik Indonesia Serikat terdiri dari 15 negara bagian bentukan Belanda, merujuk pada kesepakatan KMB bahwa investasi-investasi Belanda yang berada di Indonesia akan dilindungi dan pemerintahan baru berkewajiban untuk melunasi hutang-hutang yang diwariskan Belanda pasca pendudukan Jepang yang bernilai jutaan dollar.

Namun negara Indonesia serikat, hasil kesepakatan KMB, tidaklah bertahan lama. Meskipun negara federal itu telah lama diimpikan oleh beberapa tokoh Indonesia seperti Hatta dan Sjahrir, fakta bahwa pembentukan RIS dipan -dang sebagai dipaksakan oleh Belanda dan sebagai hasil peninggalan kolo-nialisme, telah menggiring opini ke arah negara kesatuan. Di lima belas negara bentukan Belanda, muncul tuntutan umum untuk meleburkan diri ke dalam Republik Indonesia. Pada tanggal 3 April 1950, Mohammad Natsir, Ketua Fraksi Masyumi di parlemen, mengajukan mosi integrasi kepada parlemen, yang menuntut 
agar semua negara bagian bersatu ke dalam negara kesatuan. Mosi ini mendapatkan respon positif dari parlemen. Pada tanggal 17 Agustus 1950, RIS akhirnya digantikan oleh Republik Indonesia dengan konstitusi UUDS 1950.

Perubahan atas rumusan dasar konstitusi menjadi titik balik dalam persete-ruan Hatta dengan Soekarno. Sejak tahun 1951 sampai dengan 1956, dalam masa jabatan sebagai Wakil Presiden, beberapa kali Hatta terlihat vis a vis dengan Soekarno. Di dalam parlemen, kekuatan partai politik semakin besar memberikan dukungannya terhadap pemikiran revolusioner Soekarno. Dengan demikian, telah mempersempit ruang gerak Hatta dalam pemerin-tahan, khususnya gagasannya tentang pembangunan nasional. Selama bebe-rapa tahun berikutnya, Hatta menghabiskan waktu untuk melakukan perja-lanan ke luar negeri, dengan mempromosikan kebijakan politik luar negeri bebas aktif.

Sejak Konferensi Meja Bundar, Hatta berusaha menjalankan kebijakan politik luar negeri yang independen. Ketika menulis kebijakan luar negeri Indonesia satu tahun kemudian, ia menyesalkan mentalitas blok dalam hubungan internasional, dengan menyatakan bahwa Indonesia tidak siap untuk ikut dalam blok ketiga yang dirancang untuk menjadi kekuatan penentang terhadap kedua blok raksasa. Dalam menolak blok ketiga sebagai suatu strategi kebijakan luar negeri, Hatta bukan saja menysisihkan diri dari Sjahrir, tetapi juga dari Nehru. Sudut pandang ini juga akan memisahkan dirinya dari Soekarno, tepatnya setelah penyelenggaraan Konferensi Asia-Afrika pada tahun 1955 di Bandung. Menurut Hatta, sistem blok telah melanggar semangat dasar Persatuan Bangsa-Bangsa.

Perbedaan pandangan yang terjadi secara terus-menerus antara Wakil Presiden Mohammad Hatta dengan Presiden Soekarno memuncak pada tahun 1956, yang kemudian menempatkan Hatta dalam posisi yang dile-matis. Hatta merasakan, bahwa untuk mempertahankan revolusi sosial yang digagas oleh Soekarno, ia harus menempatkan diri sebagai oposisi. Dalam hal ini, Hatta memperingatkan Natsir mengenai keinginannya untuk meng-undurkan diri sebagai Wakil Presiden. Pada tanggal 1 Desember 1956 secara resmi Hatta mengumumkan pengunduran dirinya sebagai Wakil Presiden Republik Indonesia.

\subsection{Periode Keempat ( 1956- 1980)}

Pengunduran diri Hatta sebagai Wakil Presiden, tak pelak lagi menimbulkan gejolak penentangan di beberapa daerah, khususnya Sumatera Barat, yang selama itu menjadi basis kekuatan politik Hatta. Kalangan yang kecewa dengan sikap pemerintah Pusat (Jakarta), mengorganisasi diri untuk mela-kukan perlawanan. Pada tanggal 2 Maret 1956, panglima wilayah Sulawesi Selatan, Sumual, memproklamasikan "Piagam Perjuangan Semesta" atau Permesta. Deklarasi itu menegaskan keinginannya, bahwa pemerintahan (kabinet) baru yang diusulkan Presiden jika ingin mendapatkan dukungan yang besar, mereka harus dipimpin oleh Dwitunggal Soekarno-Hatta.

Dalam kunjungannya ke beberapa daerah, Hatta menyesalkan munculnya reaksi yang berlebihan sehubungan dengan pengunduran dirinya sebagai Wakil Presiden. Hatta menegaskan, bahwa keinginannya itu bukanlah untuk menghasut timbulnya pemberontakan, melainkan ingin mencegahnya. Orang-orang Sumatera, demikian Hatta, berjanji untuk tetap menjadi bagian integral dari Indonesia. Namun demikian, mereka menolak sebuah sistem pemerintahan yang dipraktekkan di Jakarta. Sehubungan dengan itu, Hatta menuntut pemerintah untuk secepatnya melakukan perbaikan dan pem-bangunan di daerah-daerah yang selama ini diabaikan.

Di sisi lain, untuk mencegah pengaruh besar posisi Hatta dalam tubuh partai politik, Soekarno memasukkan Partai Komunisme Indonesia (PKI) dalam kabinet baru yang dibentuknya. Hal ini segera menimbulkan kekecewaan dari partai Masyumi sebagai wakil kelompok Islam. Dalam perspektif Hatta, PKI pada dasarnya merupakan bagian dari sebuah 
gerakan internasional (komunisme internasional atau komintern). Menurut Hatta, gagasan Soe-karno untuk memadukan partai-partai yang berbasiskan nasionalisme, keagamaan dan luar negeri dalam satu kabinet merupakan upaya mencampurkan air dalam minyak.

Sampai dengan tahun 1965 kelompok kiri berhasil memainkan pengaruhnya untuk mendukung gagasan revolusioner Sekarno. Perseturuan Bung Karno dengan kelompok Islam dan Angkatan Darat memuncak pada peristiwa gerakan 30 September 1965 (Gestapu), ketika PKI melancarkan Kudeta untuk memberangus para perwira tinggi Angkatan Darat yang menentang program "Nasakom", terutama Dewan Jenderal yang dicurigai menyusun agenda besar (hidden agenda) untuk menggulingkan Soekarno, termasuk A.H Nasution dan Ahmad Yani.

Namun, tidak lama setelah peristiwa Gestapu, muncul gelombang besar demontrasi mahasiswa yang menuntut pembubaran PKI. Dalam hal ini, Soekarno diminta untuk bertanggung jawab terhadap penculikan dan pem-bunuhan Dewan Jenderal. Namun, seberapa jauh Soekarno terlibat Gestapu, sampai dengan saat ini kabar itu tidak pernah jelas. Di lain pihak, Hatta meyayangkan sikap reaksioner kaum Islamis setelah peristiwa Gestapu. Hatta tidak bisa meyembunyikan kekecewaan dan aksi balas dendam yang dilakukan umat Islam terhadap PKI. Sepanjang perjalanannya ke pulau Jawa, ia meyaksikan dengan sendiri sungaisungai yang telah dilumuri oleh darah yang menyengat dari tubuh anggota PKI. Peristiwa Gestapu berakhir dengan keruntuhan rezim Soekarno pada tahun 1967, yang kemudian memunculkan nama Suharto sebagai pemimpin politik Indonesia.

\section{Kesimpulan}

Kehadiran Soeharto dan Orde Baru diharapkan membawa angin segar bagi tegaknya demokrasi di Indonesia. Dalam pada itu, Hatta menaruhkan harapan besar bahwa dirinya dan kelompoknya dapat mengambil bagian terhadap demokratisasi dan pembangunan di Indonesia. Namun, peme-rintahan militer Soeharto tidak sedikitpun memberikan ruang politik kepada Hatta dan kelompoknya. Dari catatan yang dilaporkan oleh Deliar Noer, Hatta kecewa dengan pemerintahan Orde Baru Seharto yang dinilainya sangat fasis, apalagi setelah adanya pemberitahuan bahwa Deliar Noer, seorang murid Hatta yang tekun dan disiplin, tidak boleh mengajar lagi pada tahun 1973.

Sepanjang Orde Baru, Hatta terpaksa berdiam diri melihat keadaan yang semakin memburuk, sambil berharap keadaan dapat berubah secepatnya. Ia tidak bisa menentang Presiden Soeharto secara terbuka, apalagi dengan menggunakan kekerasan yang diyakini akan menimbulkan perang saudara dan disintegrasi bangsa. Dalam usianya yang semakin senja, Hatta mengisi hari-harinya bersama keluarga dan sesekali memberikan pidato dalam diskusi dan seminar. Akibat kondisinya yang semakin memburuk, Hatta seringkali menderita sakit parah, sampai tiba waktunya ia harus mening-galkan keluarga, teman, rakyat dan negaranya pada tanggal 14 Maret 1980. Hatta wafat dalam usia 78 tahun, terhadap jasajasanya itu, bangsa Indonesia mengenangnya sebagai tokoh yang memiliki integritas dan moral yang sangat tinggi. Selamat Jalan Bung Hatta, ucap rakyat Indonesia ketika mengantarkan jenazahnya ke persemaian terakhir di Tanah Kusir. 


\section{Daftar Pustaka}

A. Mc Clelland, Charles, Theory and the International System, (terje-mahan) (Jakarta: Penerbit Rajawali, 1981).

A.H Nasution, Sejarah Perjuangan Nasional di Bidang Bersenjata (Jakarta: Mega Bookstore, 1964).

A.H. Nasution, Sekitar Perang Kemerdekaan Indonesia, (Bandung Penerbit Angkasa, 1977).

Couloumbis, Theodore A., dan $\mathrm{H}$ Wolfe, James, Introduction to Internastional Relations:Power and Justice (New Jersey: Prentice Hall, 1978).

Franz Magnis Suseno, Pemikiran Karl Marx: Dari Sosialisme Utopis Ke Revisionisme (Jakarta: PT. Gramedia Pustaka, 2000).

Fukuyama, Francis, The End of History and The Last Man (New York:The Free Press, 1993)

Hatta, Mohammad Hatta, Memoir (Jakarta: Penerbit Tintamas, 1982), h. 34

Hatta, Mohammad, "Indonesia Foreign Policy" dalam Karya Lengkap Bung Hatta Buku Ketiga, Perdamaian dan Keadilan Sosial (Jakarta:

Taqwa dan Kekuasaan," dalam Bung Hatta, (Jakarta: Penerbit Kompas, 2001 ), h. 77. Penerbit LP3ES, 2001).

Hatta, Mohammad, Kumpulan Pidato I, (Jakarta: Penerbit Gunung Agung 2002).

Hatta, Mohammad, Mendayung Antara Dua Karang (Jakarta: CV.Bulan Bintang, 1976).

Koentjaraningrat (editor), Metode-Metode Penelitian Masyarakat (Jakarta: Penerbit Gramedia,1981), h. 61-63. Kompas, kolom opini 11 Agustus 2005

Latif, Yudi, Inteligensia Muslim dan Kuasa: Genealogi Inteligensia

Muslim Indonesia Abad XX (Jakarta: Penerbit Mizan, 2006).

M.C.Ricklefs, A History of Modern Indonesia Since c. 1200 (terje-mahan) (Jakarta: PT. Serambi Ilmu Semesta, 2005).

Machiavelli, Niccolo, II Principe (terjemahan) (Jakarta: Penerbit Pustaka Gramedia, 1999), cet.1.

Mavis Rose, Indonesian Free: A Political Biography of MohammadHatta (terjemahan), (Jakarta: Penerbit Gramedia Pustaka, 1991).

Noer, Deliar, "Pencerahan Diri Hatta: Memilih antara Taqwa danKekuasaan," dalam Bung Hatta, (Jakarta: Penerbit Kompas, 2001).

R. Soeprapto, Hubungan Internasional: Sistem, Interaksi dan Perilaku (Jakarta: Penerbit Rajawali Press, 1997).

Sabir, H. Mohammad, Politik Bebas Aktif: Tantangan dan Kesempatan (Jakarta: CV. Haji Masagung, 1987).

Sudarsono, Juwono, State of Art, Hubungan Internasional Mengkaji Ulang Teori Hubungan Internasional (Jakarta: Pustaka Jaya, 1996), h.15

Suseno, Magnis, Franz, Etika Politik: Prinsip-prinsip Moral Dasar

Kenegaraan Modern (Jakarta: PT. Pustaka Gramedia, 2001).

Swasono, Edi, Sri dan Ridjal, Fauezie (edt), Satu Abad Bung Hatta: Demokrasi Kita, Politik Bebas Aktif, Ekonomi Masa Depan (Jakarta: Penerbit Universitas Indonesia, 2002).

Taufik Abdullah, "Upacara, Pengalaman dan Identitas Bangsa," Majalah Tempo, edisi khusus 17 Agustus 2005.

Widjaja, I. Wangsa, Mengenang Bung Hatta, (Jakarta: Penerbit Gunung Agung, 2002).

Zainuddin, A Rahman, "Pemikiran Politik", dalam Jurnal Ilmu Politik Volume 7 (Jakarta: Penerbit Pustaka Gramedia, 1990). 